International Journal of Plant Breeding and Genetics, 2012

ISSN 1819-3595 / DOI: 10.3923/ijpbg.2012.

(C) 2012 Academic Journals Inc.

\title{
Origin and Seed Positional Effect on Sex Ratio of Telfairia occidentalis Hook. F. Grown in Savanna Agro-ecology
}

\author{
${ }^{1}$ C.O. Aremu and ${ }^{2}$ D.B. Adewale \\ ${ }^{1}$ Department of Agronomy, Ladoke Akintola University of Technology (LAUTECH), Ogbomoso, Nigeria \\ ${ }^{2}$ Department of Plant Breeding and Seed Technology, University of Agriculture, Abeokuta, Nigeria \\ Corresponding Author: C.O. Aremu, Department of Agronomy, Ladoke Akintola University of Technology (LAUTECH), \\ Ogbomoso, Nigeria
}

\begin{abstract}
Female telfairia produce succulent and fleshy leafy vegetables with higher nutritional values than male type and therefore preferred at groceries. There is difficulty in identifying this female telfairia at seed and seedling stages. This research identified effect of seed position and fruit origin on the vigor performance and sex ratio of Telfairia occidentalis. Three seed positions of anterior, middle and posterior sections of fruits sourced from four origins of growth were studied in the nursery and field plots at the teaching and research farm of Ladoke Akintola University of Technology, Ogbomoso, Nigeria. Vigor index and percentage emergence were highest for seedlings from the anterior portions with fruits sourced from Imo and Ibadan origins. Genotypic Coefficient of Variation (GCV) and Heritability estimate in the broad sense $\left(\mathrm{H}_{\mathrm{B}}\right)$ for branching, foliage, vine length and diameter traits were also high for plants developed from anterior seed positions and therefore can be reliably selected. More female plants were sighted to have developed from the anterior positions with 3:1 and 2:1 female to male proportions for fruits sourced from Imo and Ogbomoso origins. There were difficulties in obtaining exact genetic sex ratios. This is attributed to differences in flowering time in the male and female plants. Fruits sourced from humid environment of Imo state and seeds extracted from anterior position, recorded highest seedling vigor performance and high female to male proportions for the field established plants. These findings affirm the postulation that more female plants develop from anterior seed positions if sourced from humid agro-ecologies.
\end{abstract}

Key words: Origin, seed position, sex-ratio, vigor, telfairia, traits

\section{INTRODUCTION}

Fluted pumpkin Telfairia occidentalis is an important dioecious vegetable crop belonging to the family Cucurbitaceae (Akoroda, 1990; Ogar and Asiegbu, 2005). The vegetable is widely grown in the tropics majorly in eastern part of Anambra, Imo, Abia and Ebonyi States of Nigeria. The crop is now gaining prominence in South Western Nigeria (Schippers, 2002).

As a pot herb, the leaves are rich sources of protein, carbohydrate, iron, saponin, tannins and phytic acid and therefore a good food and medicinal source (Akwaowo et al., 2000; Akanbi et al., 2007). The vegetables are succulent with vigorous yield when grown in fadama or irrigation environment. Asiegbu (1984) reported female plant to produce more vigorous plant than male plant Native farmers harvest the males for leaves and remain the females to produce fruits for edible seeds and for future planting. In the groceries, vegetables from the male plant suffer discrimination 
as housewives prefer leaves of the female plant which have vigorous and succulent appearance. Ndukwu et al. (2005) suggested need to ascertain sex proportion in different portions of Telfairia fruits. Few researchers have determined sex ratio in the field of Telfairia plants. Asiegbu (1984) and Akoroda and Adejoro (1990) using plant morphological traits; Ajibade et al. (2006) used seed biochemical content and Ogbonna (2008) considered pod portion with focus on number of sprout per portion. Sparse literatures are available on the proportion of female to male seeds in the fruit. Exploring seed position to determine sex ratio in Telfairia plant population remains a dearth in Telfairia research. Identification of female telfairia seeds prior to planting would enhance better land area utilization to produce more telfairia leaves with better nutritional quality acceptable to consumers (Schippers, 2000). These female telfairia are only recognized on field plots after plant establishment at anthesis. The objective of this study was to determine the effect of fruit origin and seed position on vigor performance and sex proportion of Telfairia occidentalis.

\section{MATERIALS AND METHODS}

Nursery operations: Two experiments comprising of nursery and field operations were carried out during the planting season of April to November 2009 at the Department of Agronomy Teaching and Research farm Ladoke Akintola, University of Technology, Ogbomoso. Thirty six wooden boxes of $75 \times 45 \mathrm{~cm}$ diameter each were used for the nursery plantings. Three large sized fluted pumpkin fruits were sourced from each of four origins of Ogbomoso, Enugu, lbadan and Imo. The fruits were cut linearly at both ends of the stigmatic scar and stalk joint. Seeds from anterior, middle and posterior positions were carefully removed from the fruit and seeds in each position sown in the wooden boxes filled with top soil. There were variations in number of seeds from each position. Three replications were used and seeds germinated and grew in the nursery for 28 days. Seedling data were recorded on four characters, viz, mean days to germination, percentage (\%) emergence, seedling vigor index and emergence index. Pod origin and agro-ecology distribution is shown in Table 1.

Seedling data collection: At five days after sowing (5 DAS) emerged seeds were counted as having germinated and percentage emergence and mean days to germination determined.

Seedling length: At four weeks after sowing (4 WAS) seedling data were collected following the method of Ellis and Roberts (1980) and Kharb et al. (1994) as:

$$
\text { Seedling emergence index }(\mathrm{SEI})=\Sigma(\mathrm{Dn}) / \Sigma \mathrm{n}
$$

where, $\mathrm{n}$ are number of seeds that emerged and $\mathrm{D}$ are days from sowing to emergence:

$$
\text { Seedling vigor index }(\mathrm{SVI})=\mathrm{SL} \times \text { Emergence } \%
$$

where, SL = seedling length $(\mathrm{cm})$ :

$$
\text { Emergence }=\left(\frac{\text { No. of seeding emergence }}{\text { No. of seeds shown }}\right) \times 100 \%
$$

$\%$ emergence were calculated only for seeds with radicles emerging through the testa and greater than $2 \mathrm{~mm}(>2 \mathrm{~mm})$. 
Int. J. Plant Breed. Genet., 2012

Table 1: Pod origin and agro-ecology distribution

\begin{tabular}{lc}
\hline Pod origin & Agro-ecology \\
\hline Ogbomoso & Guinea savanna \\
Enugu & Humid \\
Ibadan & Humid \\
Imo & Humid \\
\hline
\end{tabular}

Fields operations: Seedlings in the nursery were transplanted on the twenty fifth day after sowing (2 5DAS) to beds each measuring $7 \times 2 \mathrm{~m}$ with $1 \mathrm{~m}$ spacing between beds. Randomised complete block design with three replications were used. A seedling was placed per hole to give 16 plant stands per plot. A total of 576 plant stands were on the field prior to data collection. Plant irrigation and other cultural practices were carried out when necessary. At 110 days after seed sowing, growth, flowering and sex data were noted and collected on the established plant stands. Field data included date to $50 \%$ flowering, number of branch per plant, vine length $(\mathrm{cm})$ vine width $(\mathrm{cm})$, internode distance $(\mathrm{cm})$ number of foliage and foliage width $(\mathrm{cm})$.

Data analysis: Analysis of variance test performed using SAS, 20002.0 package of 2000. Genotypic and phenotypic coefficients of variation were calculated following the methods outlined by Falconer and Mackay (1996) as follows:

$$
\begin{gathered}
\delta^{2} g=(m g-m e) / r \\
\delta^{2} p=\delta^{2} g+\delta^{2} e
\end{gathered}
$$

Where:

$\delta^{2} \mathrm{~g}=$ Genotypic coefficient of variance

$\delta^{2} \mathrm{p}=$ Phenotypic coefficient of variance

$\mathrm{mg}=$ Genotype mean square

me $=$ Error mean square

$\delta^{2} \mathrm{e}=$ Error variance

$r \quad=$ No. of replications

\section{RESULTS}

Telfairia nursery trial recorded differences in the seedling traits for the three seed positions across the fruit origin (Table 2). Fruits sourced from Imo gave high percentage of emergence and vigor index for seedlings extracted from anterior position (89\%; 11.0). This was closely followed by Ibadan $(85 \%, 7.7)$ and Ogbomoso $(70.2 \% ; 7.5)$ anterior seed positions, respectively. Mean germination time was shortest for seeds in the middle position of Enugu origin (5.5) which germinated within 6 days after sowing. Following the seed positions in the fruits (Table 3), there were wide and significant variations in the performance of the seven traits evaluated. The seeds from each of the three positions and origins flowered at different time as the days to flowering differed significantly using treatment variation source (118.6). The established plants from the three seed positions and origins recorded wide variations in their vine thickness and leaf wideness $(0.51 ; 5.2)$. Vine nodal distance did not show significant variation. Comparatively, effect of seed position on trait performance recorded somewhat higher genotypic than phenotypic variation. 
Int. J. Plant Breed. Genet., 2012

Table 2: Seed position on germination and seedling vigor

\begin{tabular}{|c|c|c|c|c|c|c|}
\hline Seed position & Percentage & Number of seed & Emergence \% & $\begin{array}{l}\text { Mean days to } \\
\text { germination }\end{array}$ & $\begin{array}{l}\text { Seedling } \\
\text { vigor index } \\
\end{array}$ & $\begin{array}{l}\text { Seedling emergence } \\
\text { index }\end{array}$ \\
\hline \multirow[t]{3}{*}{ Ogbomoso } & Anterior & 46 & 70.2 & 8.3 & 7.5 & 4.2 \\
\hline & Middle & 43 & 69.7 & 7.2 & 6.4 & 3.8 \\
\hline & posterior & 40 & 41.0 & 6.9 & 4.8 & 3.5 \\
\hline \multirow[t]{3}{*}{ Enugu } & Anterior & 44 & 67.8 & 8.1 & 6.7 & 4.5 \\
\hline & Middle & 35 & 59.8 & 5.5 & 5.0 & 2.9 \\
\hline & posterior & 41 & 52.8 & 6.2 & 5.3 & 3.7 \\
\hline \multirow[t]{3}{*}{ Ibadan } & Anterior & 46 & 85.0 & 8.7 & 7.7 & 4.8 \\
\hline & Middle & 42 & 71.2 & 7.2 & 7.3 & 3.6 \\
\hline & posterior & 39 & 48.1 & 6.6 & 6.9 & 3.3 \\
\hline \multirow[t]{3}{*}{ Imo } & Anterior & 43 & 89.3 & 8.9 & 11.0 & 5.4 \\
\hline & Middle & 48 & 65.2 & 8.5 & 6.7 & 5.2 \\
\hline & posterior & 46 & 58.1 & 7.2 & 6.5 & 4.0 \\
\hline
\end{tabular}

Table 3: Mean square in the analysis of variance of field traits in Telfairia plants

\begin{tabular}{lcccccccc}
\hline $\begin{array}{l}\text { Source of } \\
\text { variation }\end{array}$ & Df & $\begin{array}{l}\text { Days to } 50 \% \\
\text { flowering }\end{array}$ & $\begin{array}{l}\text { Number of } \\
\text { branch/plant }\end{array}$ & Vine length $(\mathrm{cm})$ & Vine width $(\mathrm{cm})$ & $\begin{array}{l}\text { Internode } \\
\text { distance }(\mathrm{cm})\end{array}$ & $\begin{array}{l}\text { Number of } \\
\text { foliage }\end{array}$ & $\begin{array}{l}\text { Foliage } \\
\text { width }(\mathrm{cm})\end{array}$ \\
\hline Block & 2 & $0.72^{*}$ & 0.27 & 9.4 & $0.39^{*}$ & 2.7 & $16.4^{* *}$ & 0.06 \\
Treatment & 11 & $118.6^{* *}$ & $8.04^{* *}$ & $578.6^{* *}$ & $0.51^{* *}$ & 7.9 & $2418.1^{* *}$ & $5.20^{* *}$ \\
\hline
\end{tabular}

* Significant at 5\%; ** Significant at $1 \%$

Table 4: Positional mean values, genotypic and phenotypic coefficient of variation and heritability estimates in telfairia

\begin{tabular}{|c|c|c|c|c|c|}
\hline Trait & Position & Mean value & Genotypic (CV) \% & Phenotypic (CV) \% & Broad sense heritability \\
\hline \multirow[t]{3}{*}{ Days to $50 \%$ flower } & Anterior & 98.3 & 38.2 & 57.2 & 49.2 \\
\hline & Middle & 81.2 & 44.3 & 50.1 & 45.2 \\
\hline & Posterior & 87.0 & 42.1 & 49.2 & 30.2 \\
\hline \multirow[t]{3}{*}{ Number of branch per plant } & Anterior & 35.1 & 41.3 & 57.2 & 72.2 \\
\hline & Middle & 28.4 & 51.3 & 55.6 & 82.7 \\
\hline & Posterior & 20.7 & 54.2 & 53.5 & 40.2 \\
\hline \multirow[t]{3}{*}{ Vine length $(\mathrm{cm})$} & Anterior & 3.2 & 45.7 & 35.3 & 80.2 \\
\hline & Middle & 2.7 & 54.4 & 37.6 & 85.4 \\
\hline & Posterior & 1.9 & 33.3 & 28.5 & 65.2 \\
\hline \multirow[t]{3}{*}{ Vine width $(\mathrm{cm})$} & Anterior & 1.4 & 57.1 & 16.8 & 60.3 \\
\hline & Middle & 0.9 & 15.2 & 16.0 & 70.4 \\
\hline & Posterior & 1.1 & 17.2 & 18.7 & 50.7 \\
\hline \multirow[t]{3}{*}{ Internode distance $(\mathrm{cm})$} & Anterior & 10.7 & 18.1 & 18.6 & 69.5 \\
\hline & Middle & 7.9 & 17.2 & 16.5 & 30.2 \\
\hline & Posterior & 10.1 & 20.3 & 21.4 & 28.2 \\
\hline \multirow[t]{3}{*}{ Number of foliage } & Anterior & 123.7 & 67.1 & 52.1 & 58.7 \\
\hline & Middle & 100.2 & 51.7 & 57.6 & 50.3 \\
\hline & Posterior & 120.7 & 50.2 & 21.6 & 29.7 \\
\hline \multirow[t]{3}{*}{ Foliage width $(\mathrm{cm})$} & Anterior & 4.7 & 63.2 & 21.6 & 53.6 \\
\hline & Middle & 3.9 & 24.8 & 16.6 & 79.2 \\
\hline & Posterior & 4.0 & 22.0 & 16.9 & 50.2 \\
\hline
\end{tabular}

Number and wideness of foliage in the anterior seed position (Table 4) were the most genetically variable (67.1 and $63.2 \%$ ) with moderately high heritability estimates of $58.7 ; 53.6 \%$, respectively. 
Int. J. Plant Breed. Genet., 2012

Table 5: Positional sex ratio in Four Telfairia origins

\begin{tabular}{|c|c|c|c|c|c|c|c|c|}
\hline & & \multirow[b]{2}{*}{ Number of plant } & \multicolumn{2}{|c|}{ Established plant } & \multicolumn{2}{|c|}{ Sex ratio } & \multicolumn{2}{|c|}{ Percentage } \\
\hline \multicolumn{2}{|c|}{ Origin and position } & & Male & Female & Male & Female & Male & Female \\
\hline \multirow[t]{3}{*}{ Ogbomoso } & Anterior & 48 & 15 & 29 & 1 & 2 & 33.3 & 66.1 \\
\hline & Middle & 45 & 30 & 21 & 1 & 1 & 47.2 & 56.8 \\
\hline & Posterior & 45 & 27 & 15 & 1 & 1 & 46.1 & 49.7 \\
\hline \multirow[t]{3}{*}{ Enugu } & Anterior & 46 & 19 & 26 & 1 & 1 & 43.5 & 56.5 \\
\hline & Middle & 47 & 23 & 24 & 1 & 1 & 56.2 & 52.7 \\
\hline & Posterior & 45 & 28 & 15 & 2 & 1 & 68.3 & 31.8 \\
\hline \multirow[t]{3}{*}{ Ibadan } & Anterior & 40 & 15 & 22 & 1 & 1 & 40.0 & 60.1 \\
\hline & Middle & 47 & 19 & 26 & 1 & 1 & 41.5 & 58.6 \\
\hline & Posterior & 45 & 20 & 23 & 1 & 1 & 46.5 & 53.6 \\
\hline \multirow[t]{3}{*}{ Imo } & Anterior & 45 & 11 & 32 & 1 & 3 & 22.5 & 70.4 \\
\hline & Middle & 48 & 21 & 24 & 1 & 1 & 48.3 & 51.8 \\
\hline & Posterior & 46 & 24 & 19 & 1 & 1 & 57.1 & 43.1 \\
\hline
\end{tabular}

Even though branching and nodal distance recorded low genetic variation; the associated heritability values were high (72.2 and $69.5 \%)$.

Field established plants flowered with different male to female ratios across the seed positions (Table 5). Telfairia seeds sourced from the humid agro-ecologies of Imo and Ibadan (Table 1), recorded calculated male to female trait performance ranges of between 40 and $60 \%$ across the seed positions. Anterior seed positions from Ogbomoso and Imo developed two and three times $2: 1 ; 3.1$ more female to male plant stands on the field with 66.1 and $70.4 \%$ female proportion higher than male established plants of 33.3 and $22.5 \%$ values.

\section{DISCUSSION}

Seeds in the anterior positions numbered more split testas at the time of fruit splitting than seeds in the middle and posterior ends. This could have accounted for the highest emergence proportion and vigor performance index recorded in the seedlings from anterior position. Better still, the fruit stalk linearly closer to the anterior end of the Telfairia fruit, may have allowed release of more photosynthase accumulate from the leaves to the anterior positioned seeds. Early seed germination in telfairia can be achieved using seeds extracted from the anterior seed position. This finding contradicts the work of Akoroda and Adejoro (1990) that seed split in telfairia can be achieved using sawdust growth medium. According to Stefano et al. (2004), many factors affect Telfairia seed quality and seedling vigour. Odiyi, (2003) identified multiple seedling from one seed to affect seedling vigor. Yamauchi and Winn (1996) identified soil condition as an indicator of seedling vigor in rice. Again level of accumulation of biochemical content in the cotyledonous seeds may have justified the variation in the number of seeds that emerged and the seedlings that recorded vigorous performance. This assertion was opinionated by Ajibade et al. (2006), in their study on effect of biochemical qualities on sex proportions in telfairia crop and runs contrary to the findings of this research.

The Phenolic variations in the trait performance with respect to foliage, branching and vine traits can be attributed to the proportion of male to female plant numbers present in the established Telfairia field crop. Wilman and Asiegbu (1982) identified vine diameter and fresh leaf weight as 
contributors of yield variation in both male and female plants of Telfairia and runs contrary to this research which identified more specifically that genetic differences in traits associated with each of the seed positions and origins accounted for the yield variations in the male and female sexes. This report also disagrees with the findings of Ogbonna (2008), that sex and yield variations in telfairia are imposed by female plant correlation with vine length at flower initiations. On the other hand, diverse genetic background of the Telfairia origin used in these findings may have reposed the variations observed in the Phenolic and selection parameters. This is in agreement with the work of Ariyo (1995) that high genotypic variation for flowering and branching traits and that such variation is caused by wide genetic background of the cowpea genotypes used. High heritability estimates associated with foliage number and wideness as well as vine and branching traits suggest the reliability in selecting for these traits developing from anterior positions of Telfairia fruits sourced from humid environments. This is supported by Karthikeyan et al. (2010) and Ullah et al. (2011) that high heritability values in traits make for effective superior genotype selection. That germination number and vigor index were high for seedlings emerging from anterior position are suggestive that seedling from anterior position could produce more female than male plants stands on a given Telfairia field plots. The postulation of Asiegbu (1984), that sex population of field Telfairia plants be adjusted to accommodate more female than male plants for grocery acceptance, is justified by the findings of this research. However, this finding runs contrary to the work of Ogbonna (2008) that seeds from middle position produced more female plants.

The difficulty in obtaining exact sex proportion as evident in the calculated differences in the male to female percentages is as a result of variations in the flowering periods of both male and female Telfairia plants. During the cropping season, the male flowered between 90-96 days with the staminate flowers borne in a racemose inflorescence. Whereas, the single flutes (female flowers) were observed between 105-115 days after planting and borne on the leaf axils. Sexes are only identified with certainty at flowering; however, better information on sex proportion could also be obtained especially at the seed level if investigations incorporate more fruit origins and more seed positions to include each longitudinal row in a given fruit.

\section{CONCLUSION}

This study sufficiently informed that fruit origin and seed position accounted for variations in the performance of Telfairia occidentalis. And that breeding for increased number and wideness of foliage could be successful in Guinea Savanna agro-ecology. The possibility is because foliage and vine branching performance of plants that developed from anterior positions gave high genetic variation with high selection parameter estimates. High seedling vigor in addition to high proportion of female to male plants in plants from anterior position strongly affirm that female seeds are located in the anterior positions of seeds sourced from humid environments.

Seed origin and positions are further investigated to accommodate more of such origins and positions so as to provide more sufficient and richer literature on improving female proportion in vegetable field crop of Telfairia.

\section{ACKNOWLEDGMENT}

The authors are grateful to Dr. Azeez, M.A of the department of pure and Applied Biology, LAUTECH, Ogbomoso Nigeria, for his technical assistance during the conduct and paper writing of this research. 
Int. J. Plant Breed. Genet., 2012

\section{REFERENCES}

Ajibade, S.R., M.O. Balogun, O.O. Afolabi and M.D. Kupolati, 2006. Sex differences in biochemical contents of Telfairia occidentalis Hook F. J. Food Agric. Environ., 4: 155-156.

Akanbi, W.B., T.A. Adebayo, O.A. Togun, A.S. Adeyeye and O.A. Olaniran, 2007. The use of compost as foliar spray nutrient source and botanical insecticide in Telfairia occidentalis. World J. Agric. Sci., 3: 642-652.

Akoroda, M.O., 1990. Ethnobotany of Telfairia occidentalis (Cucurbitaceae) among Igbos of Nigeria. Econ. Bot., 44: 29-39.

Akoroda, M.O. and M.A. Adejoro, 1990. Patterns of vegetative and sexual development of Telfairia occidentalis Hook. F. Trop. Agric., 67: 243-247.

Akwaowo, E.U., B.A. Ndon and E.U. Etuk, 2000. Minerals and antinutrients in fluted pumpkin (Telfaria occidentalis Hook f.). Food Chem., 70: 235-240.

Ariyo, O.J. 1995. Genetic variability, correlations and path coefficient analysis of components of seed yield in cowpea (Vigna unguiculata). Pertanika J. Trop. Agric. Sci., 18: 63-70.

Asiegbu, J.E. 1984. Characterization of sexes in Telfairia occidentalis: Growth and yield characteristics of male and female crops. Sci. Hortic., 20: 12-15.

Ellis, R.H. and E.H. Roberts, 1980. Towards a Rational Basis for Testing Seed Quality in Seed Production. Ist Edn., Butterworths, London, pp: 605-635.

Falconer, D.S. and T.F.C. Mackay, 1996. Introduction to Quantitative Genetics. 4th Edn. Longman, England, pp: 464.

Karthikeyan, P., Y. Anbuselvam, R. Elangaimannan and M. Venkatesan, 2010. Variability and heritability studies in rice (Oryza sativa L.) under coastal salinity. Electronic J. Plant Breed., 1: 196-198.

Kharb, R.P., B.P.S. Lather and D.P. Deswal, 1994. Prediction of field emergence through heritability and Genetic advance of vigour parameters. Seed Sci. Technol., 22: 461-466.

Ndukwu, B.C., G.C. Obute and I.L. Wary-Toby, 2005. Tracking sexual dimorphism in Telfairia occidentalis Hook, f. (Cucurbitaceae) with morphological and molecular markers. Afr. J. Biotechnol., 4: 1245-1249.

Odiyi, A.C., 2003. Developmental patterns of the multiple seedling trait in Telfairia occidentalis Hook, f. J. Sustainable Agric. Environ., 5: 317-325.

Ogar, E.A. and J.E. Asiegbu, 2005. Effect of fertilizer rates and cutting frequency on the marketable vegetable and pod yields of in fluted pumpkin in Southern Nigeria. Agroscience, 4.1: 66-69.

Ogbonna, P.E., 2008. Pod portion and type effects on sex growth and yield in fluted pumkin. African Crop Sci. J., 16: 185-190.

SAS, 2000. SAS Users Guide. SAS Institute Inc., Cary, NC.

Schippers, R.R., 2000. African Indigenous Vegetables: An Overview of the Cultivated Species. University of Greenwich and the ACP-EU Technical Centre for Agricultural and Rural Cooperatio, UK., Pages: 214.

Schippers, R.R., 2002. African Indigenous Vegetables: An Overview of the Cultivated Species. Revised Edn., Natural Resources International Limited, Aylesford, United Kingdom.

Stefano, P., R. Dris and F. Rapparini, 2004. Influence of growing conditions on yield and quality of cherry. J. Food, Agri. Env., 2: 307-309. 
Ullah, M.Z., M.K. Bashar, M.S.R. Bhuiyan, M. Khalequzzaman and M.J. Hasan, 2011. Interrelationship and cause-effect analysis among morpho-physiological traits in biroin rice of Bangladesh. Int. J. Plant Breed. Genet., 5: 246-254.

Wilman, D. and J.E. Asiegbu, 1982. Effects of variety, cutting interval and nitrogen application on morphology and development of stolons and leaves of white clover. Grass and forage Sci., 37: 15-27.

Yamauchi, M. and T. Winn, 1996. Rice seed vigor and seedling establishment in anaerobic soil. Crop Sci., 36: 680-686. 